\title{
Decreased expression of $17 \beta$-hydroxysteroid dehydrogenase type 1 is associated with DNA hypermethylation in colorectal cancer located in the proximal colon
}

\author{
Agnieszka Anna Rawłuszko', Karolina Horbacka², Piotr Krokowicz² and Paweł Piotr Jagodziński ${ }^{*}$
}

\begin{abstract}
Background: The importance of $17 \beta$-estradiol (E2) in the prevention of large bowel tumorigenesis has been shown in many epidemiological studies. Extragonadal E2 may form by the aromatase pathway from androstenedione or the sulfatase pathway from estrone (E1) sulfate followed by E1 reduction to E2 by 17- $\beta$ hydroxysteroid dehydrogenase (HSD17B1), so HSD17B1 gene expression may play an important role in the production of E2 in peripheral tissue, including the colon.
\end{abstract}

Methods: HSD17B1 expression was analyzed in colorectal cancer cell lines (HT29, SW707) and primary colonic adenocarcinoma tissues collected from fifty two patients who underwent radical colon surgical resection. Histopathologically unchanged colonic mucosa located at least 10-20 cm away from the cancerous lesions was obtained from the same patients. Expression level of HSD17B1 using quantitative PCR and western blot were evaluated. DNA methylation level in the $5^{\prime}$ flanking region of HSD17B1 CpG rich region was assessed using bisulfite DNA sequencing and HRM analysis. The influence of DNA methylation on HSD17B1 expression was further evaluated by ChIP analysis in HT29 and SW707 cell lines. The conversion of estrone (E1) in to E2 was determined by electrochemiluminescence method.

Results: We found a significant decrease in HSD17B1 transcript $(p=0.0016)$ and protein $(p=0.0028)$ levels in colorectal cancer (CRC) from the proximal but not distal colon and rectum. This reduced HSD17B1 expression was associated with significantly increased DNA methylation $(p=0.003)$ in the CpG rich region located in the $5^{\prime}$ flanking sequence of the HSD17B1 gene in CRC in the proximal but not distal colon and rectum. We also showed that 5-dAzaC induced demethylation of the $5^{\prime}$ flanking region of HSD17B1, leading to increased occupation of the promoter by Polymerase II, and increased transcript and protein levels in HT29 and SW707 CRC cells, which contributed to the increase in E2 formation.

Conclusions: Our results showed that reduced HSD17B1 expression can be associated with DNA methylation in the $5^{\prime}$ flanking region of HSD17B1 in CRC from the proximal colon.

\section{Background}

Colorectal cancer $(\mathrm{CRC})$ is the third in the United States [1] and second in Europe [2] cause of malignant disease deaths among adults. Population based studies have shown significant gender differences in CRC incidence

\footnotetext{
* Correspondence: pjagodzi@am.poznan.pl

'Department of Biochemistry and Molecular Biology, Poznań University of Medical Sciences, Poznań Poland

Full list of author information is available at the end of the article
}

and mortality [3]. CRC occurrence is more frequent among men than in pre-menopausal women, which suggests a protective role of $17-\beta$-estradiol (E2) in the development of this cancer [3-5]. Moreover, many casecontrol and cohort studies showed an inverse relationship between the risk of CRC incidence and the use of hormone replacement therapy by post-menopausal women [6,7]. Although E2 is mainly biosynthesized by the ovaries, this hormone can also be produced in

\section{Ciomed Central}


peripheral tissues in both genders [8]. Extragonadal E2 can be formed by the aromatase pathway from the androstenedione or the sulfatase pathway from estrone (E1) sulfate, followed by E1 reduction to E2 by 17- $\beta$ hydroxysteroid dehydrogenase (HSD17B1) [8,9]. Therefore, HSD17B1 gene expression may play an important role in the production of E2 in peripheral tissue. HSD17B1 transcription may start from distal or proximal promoters, forming, respectively, the long (2.3-kb) or short $(1.3-\mathrm{kb})$ transcript, but the short mRNA is thought to be translated into the HSD17B1 protein (Additional file 1) [10-13].

Epigenetics involve variable usage of DNA due to chromatin modifications without disturbances in the DNA sequence [14]. The low level of DNA methylation within 5'-CpG-3' dinucleotides may relate to the activation of transcription or chromosomal instability $[14,15]$. It has been shown that, similarly to genetic mutations, hypermethylation or hypomethylation of gene promoters may change the expression of cancer related genes in different malignancies, including CRC [14]. DNA methylation is carried out by DNA methyltransferases (DNMTs), and increased levels of some DNMTs account for transcriptional silencing of cancer protective genes [15].

We studied HSD17B1 transcript and protein levels in primary cancerous tissue and histopathologically unchanged colorectal tissue from the same fifty two patients with CRC. We also evaluated the effect of 5Aza-2'-deoxycytidine (5-dAzaC), a DNMTs inhibitor, on HSD17B1 transcript and protein levels in HT29 and SW707 CRC cells. Moreover, we determined the level of methylation in the 5 ' flanking region of HSD17B1 in primary cancerous and histopathologically unchanged colonic tissues as well as HT29 and SW707 CRC cells treated with 5-dAzaC.

\section{Methods}

\section{Patient material}

Primary colonic adenocarcinoma tissues were collected between June 2009 and June 2010 from fifty two patients who underwent radical colon surgical resection at the Department of General and Colorectal Surgery, Poznań University of Medical Sciences, Poland (Table 1). Histopathologically unchanged colonic mucosa located at least $10-20 \mathrm{~cm}$ away from the cancerous lesions was obtained from the same patients. Samples were immediately snap-frozen in liquid nitrogen and stored at $-80{ }^{\circ} \mathrm{C}$ until RNA/DNA/protein isolation. At the time of surgery, the median and mean age of the patients was 70 years (range 39-85) and $68.36 \pm 11.7$ years, respectively. Two of the patients exhibited T1 tumour stage, nine of the patients exhibited T2 tumour stage, thirty seven patients exhibited T3 tumour stage and four patients exhibited T4 tumour stage. Written informed consent was obtained from all participating individuals. The procedures of the study were approved by the Local Ethical Committee of Poznań University of Medical Sciences.

\section{Antibodies and Reagents}

Goat polyclonal (Gp) anti-HSD17B1 antibodies (Ab) (C18 ), donkey anti-goat horseradish peroxidase (HRP)conjugated $\mathrm{Ab}$, anti-actin $\mathrm{HRP}$-conjugated $\mathrm{Ab}$ (clone I19) and anti-Polymerase II (Pol II)-rabbit polyclonal Ab (H-224) were provided by Santa Cruz Biotechnology (Santa Cruz, CA). E1, 5-dAzaC was purchased from Sigma-Aldrich Co. (St. Louis, MO). Goat anti-rabbit HRP conjugated Ab was provided by DAKO (Glostrup, Denmark).

\section{Cell culture}

HT29 colon cancer cells were obtained from the American Type Culture Collection (Rockville, MD) and SW707 CRC cells were kindly provided by the Institute of Immunology and Experimental Therapy of the Polish Academy of Sciences. These cells were cultured in DMEM GibcoBRL (Grand Island, NY) containing 10\% heat-inactivated fetal bovine serum (FBS) and $2 \mathrm{mM}$ glutamine. To determine the effect of 5-dAzaC on HSD17B1 transcript and protein levels, the HT29 and SW707 cells were cultured for $24 \mathrm{~h}$ in phenol red-free DMEM GibcoBRL (Grand Island, NY) supplemented with $10 \%$ charcoal-dextran-stripped FBS from SigmaAldrich Co. (St. Louis, MO). Cells were then cultured for $6,12,24,36$ and $48 \mathrm{~h}$ either in the absence or in the presence of 5-dAzaC at concentrations of $0.33,0.66$ and $1.00 \mu \mathrm{M}$. These cells were used for total RNA isolation, western blotting, chromatin immunoprecipitation (ChIP) assay, and bisulfite sequencing.

\section{Reverse transcription and real-time quantitative polymerase chain reaction (RQ-PCR) analysis of the HSD17B1 transcript levels}

The total RNA from primary tissues of patients with CRC and from HT29 and SW707 cells was isolated according to the method of Chomczyński and Sacchi (1987) [16]. RNA samples were treated with DNase I, quantified, and reverse-transcribed into cDNA. RQ-PCR was carried out in a Light Cycler real-time PCR detection system from Roche Diagnostics GmbH, (Mannheim, Germany) using SYBR ${ }^{\circledR}$ Green I as detection dye. The target cDNA was quantified by relative quantification method using a calibrator for primary tissue or respective controls for HT29 and SW707 cells. The calibrator was prepared as a cDNA mix from all of the patients' samples and successive dilutions were used to create a standard curve as described in Relative 
Table 1 HSD17B1 transcript and protein levels in primary cancerous and histopathologically unchanged tissue samples from patient with CRC.

\begin{tabular}{|c|c|c|c|c|c|c|}
\hline \multicolumn{2}{|l|}{$\mathrm{n}=52$} & \multicolumn{2}{|c|}{ Primary cancerous tissues } & \multicolumn{2}{|c|}{ Histopathologically unchanged tissues } & \multirow[t]{2}{*}{$\mathrm{P}^{c}$} \\
\hline & & Median (range) & Mean ( \pm SD) & Median (range) & Mean ( \pm SD) & \\
\hline \multicolumn{7}{|l|}{ Age (Years) } \\
\hline \multirow[t]{2}{*}{$<60$} & 10 & $3.511(2.109-3.868)^{a}$ & $3.282 \pm 0.5921^{\mathrm{a}}$ & $3.415(2.726-5.107)^{\mathrm{a}}$ & $3.611 \pm 0.6309^{a}$ & $0.2450^{\mathrm{a}}$ \\
\hline & & $2.634(1.681-3.218)^{b}$ & $2.579 \pm 0.5243^{b}$ & $2.620(2.108-3.398)^{b}$ & $2.719 \pm 0.4843^{b}$ & $0.5423^{b}$ \\
\hline \multirow[t]{2}{*}{$>60$} & 42 & $3.531(2.071-5.227)^{a}$ & $3.569 \pm 0.6649^{a}$ & $3.692(2.790-5.785)^{a}$ & $3.834 \pm 0.6251^{a}$ & $0.1087^{\mathrm{a}}$ \\
\hline & & $2.728(1.728-4.023)^{b}$ & $2.720 \pm 0.4702^{b}$ & $2.952(1.364-3.472)^{b}$ & $2.835 \pm 0.4913^{b}$ & $0.1121^{b}$ \\
\hline \multicolumn{7}{|l|}{ Gender } \\
\hline \multirow[t]{2}{*}{ Female } & 20 & $3.384(2.109-4.455)^{a}$ & $3.371 \pm 0.5676^{a}$ & $3.449(2.726-5.785)^{a}$ & $3.719 \pm 0.7333^{a}$ & $0.2340^{\circ}$ \\
\hline & & $2.793(1.681-3.218)^{b}$ & $2.666 \pm 0.4767^{b}$ & $2.811(2.108-3.472)^{b}$ & $2.844 \pm 0.4065^{b}$ & $0.2119^{b}$ \\
\hline \multirow[t]{2}{*}{ Male } & 32 & $3.571(2.071-4.653)^{a}$ & $3.557 \pm 0.6523^{a}$ & $3.857(2.790-5.259)^{a}$ & $3.890 \pm 0.5855^{a}$ & $0.0388^{\circ}$ \\
\hline & & $2.702(1.728-4.023)^{b}$ & $2.713 \pm 0.4941^{b}$ & $2.962(1.364-3.449)^{b}$ & $2.792 \pm 0.5395^{b}$ & $0.2832^{b}$ \\
\hline \multicolumn{7}{|l|}{ CRC localization } \\
\hline \multirow[t]{2}{*}{ Proximal colon (cecum to transverse) } & 20 & $3.507(2.666-4.455)^{a}$ & $3.427 \pm 0.4350^{a}$ & $3.874(3.050-5.785)^{a}$ & $4.057 \pm 0.7488^{a}$ & $0.0016^{2}$ \\
\hline & & $2.793(1.681-3.218)^{b}$ & $2.666 \pm 0.4767^{b}$ & $2.811(2.108-3.472)^{b}$ & $2.844 \pm 0.4065^{b}$ & $0.0028^{b}$ \\
\hline \multirow[t]{2}{*}{ Distal colon (splenic flexture to sigmoid) } & 12 & $3.214(2.071-4.313)^{a}$ & $3.218 \pm 0.7760^{a}$ & $3.449(2.726-4.587)^{a}$ & $3.630 \pm 0.6372^{a}$ & $0.1685^{\circ}$ \\
\hline & & $2.798(1.772-3.254)^{b}$ & $2.691 \pm 0.4777^{b}$ & $2.860(1.364-3.391)^{b}$ & $2.619 \pm 0.6350^{b}$ & $0.7763^{b}$ \\
\hline \multirow[t]{2}{*}{ Rectum } & 20 & $3.544(2.523-4.653)^{a}$ & $3.657 \pm 0.6011^{a}$ & $3.564(3.226-4.862)^{a}$ & $3.762 \pm 0.500^{a}$ & $0.8839^{\circ}$ \\
\hline & & $2.951(1.728-3.398)^{b}$ & $2.815 \pm 0.4436^{b}$ & $2.988(2.019-3.383)^{b}$ & $2.913 \pm 0.3871^{b}$ & $0.5019^{b}$ \\
\hline \multicolumn{7}{|l|}{ Histologic grade } \\
\hline \multirow[t]{2}{*}{ G1 } & 4 & $4.059(2.362-4.402)^{a}$ & $3.721 \pm 0.9467^{a}$ & $4.431(3.123-5.259)^{a}$ & $4.311 \pm 0.9076^{a}$ & $0.4026^{\circ}$ \\
\hline & & $2.926(2.586-3.040)^{b}$ & $2.870 \pm 0.2060^{b}$ & $2.789(2.026-3.147)^{b}$ & $2.688 \pm 0.5370^{b}$ & $0.5506^{\mathrm{b}}$ \\
\hline \multirow[t]{2}{*}{ G2 } & 35 & $3.379(2.109-4.621)^{a}$ & $3.363 \pm 0.5385^{a}$ & $3.524(2.726-5.785)^{a}$ & $3.681 \pm 0.5619^{a}$ & $0.0335^{\circ}$ \\
\hline & & $2.647(1.681-4.023)^{b}$ & $2.649 \pm 0.4993^{b}$ & $2.933(2.019-3.472)^{b}$ & $2.863 \pm 0.4114^{b}$ & $0.0659^{b}$ \\
\hline \multirow[t]{2}{*}{ G3 } & 13 & $3.875(2.071-4.839)^{a}$ & $3.807 \pm 0.7092^{a}$ & $4.043(2.790-5.227)^{a}$ & $4.165 \pm 0.7346^{a}$ & $0.2587^{2}$ \\
\hline & & $2.676(1.845-3.431)^{b}$ & $2.670 \pm 0.5098^{b}$ & $3.023(1.364-3.449)^{b}$ & $2.763 \pm 0.6858^{b}$ & $0.5114^{b}$ \\
\hline
\end{tabular}

The HSD17B1 transcript levels ${ }^{\mathrm{a}}$ were standardized by the geometric mean of PBGD and hMRPL19 CDNA and expressed as decimal logarithm of multiples of these CDNA copies in calibrator. ${ }^{b}$ The amount of western blot-detected proteins was presented as the decimal logarithm HSD17B1 to $\beta$-actin band optical density ratio. ' Unpaired, two-tailed $t$-test or U-Mann-Whitney test.

Quantification Manual Roche Diagnostics GmbH, (Mannheim, Germany). For amplification, $1 \mu \mathrm{l}$ of cDNA solution was added to $9 \mu$ of $\mathrm{IQ}^{\mathrm{TM}} \mathrm{SYBR}^{\circledR}$ Green Supermix Bio-Rad Laboratories Inc. (Hercules, CA) and primers (Additional file 1, Additional file 2). The quantity of transcript of HSD17B1 in each sample was standardized by the geometric mean of porphobilinogen deaminase (PBGD) and human mitochondrial ribosomal protein L19 (hMRPL19) cDNA levels (Additional file 2) $[17,18]$. The transcript levels in patient tissues were expressed as multiplicity of these cDNA concentrations in the calibrator. In HT29 and SW707 cells, transcript levels were presented as multiplicity of the respective controls.

\section{Western blotting analysis}

Primary tissue from patients with CRC and HT29 and SW707 cells were treated with lysis RIPA buffer, and $40 \mu \mathrm{g}$ of protein were resuspended in sample buffer and separated on $12 \%$ Tris-glycine gel using sodium dodecyl sulfate-polyacrylamide gel electrophoresis (SDS-PAGE). Gel proteins were transferred to a polyvinylidene fluoride (PVDF) membrane, which was blocked with 5\% milk in Tris/HCl saline/Tween buffer. Immunodetection of bands was performed with Gp anti-HSD17B1 Ab (C-18), followed by incubation with donkey anti-goat HRP-conjugated $\mathrm{Ab}$. To ensure equal protein loading of the lanes, the membrane was re-stripped and incubated with anti-actin HRPconjugated $\mathrm{Ab}$ (clone I-19). Bands were revealed using ECL kit and Hyperfilm ECL Amersham (Piscataway, NJ). The amounts of HSD17B1 protein was presented as the HSD17B1 to- $\beta$-actin band optical density ratio. For HT29 and SW707 cells cultured in the absence of 5-dAzaC, the ratio of HSD17B1 to $\beta$-actin was assumed to be 1 .

\section{DNA methylation evaluation by bisulfite sequencing}

Genomic DNA was isolated using DNA Mammalian Genomic Purification Kit purchased from Sigma-Aldrich Co. (St. Louis, MO). One $\mu \mathrm{g}$ of genomic DNA was subjected to bisulfite conversion of cytosine to uracil according to EZ DNA Methylation Kit ${ }^{\mathrm{TM}}$ procedure 
from Zymo Research Corporation (Orange, CA). The position of CpG islands (chr17: 37953426 - 37954 646) and binding sites of transcription factors located in the 5 ' flanking region of the promoter was determined by online programs [19-21] (Additional file 1). A DNA fragment containing $31 \mathrm{CpG}$ dinucleotides was amplified from the bisulfite-modified DNA by the primer pair (chr17: 37953 392-37 953 917) (Additional file 1, Additional file 2) complementary to the bisulfite-DNA modified sequence. PCR amplification was performed by FastStart Taq DNA Polymerase from Roche Diagnostic GmbH (Penzberg, Germany). The PCR products were purified using Agarose Gel DNA Extraction Kit Roche (Mannheim, Germany) with subsequent cloning into pGEM-T Easy Vector System I Promega (Madison, WI) and transformation into TOPO10 E. coli strain cells. Plasmid DNA isolated from ten positive bacterial clones was used for commercial sequencing of the cloned fragment of DNA. The results of bisulfite sequencing were assessed and presented using BiQ analyzer software and the Bisulfite sequencing Data Presentation and Compilation (BDPC) web server, respectively $[22,23]$.

\section{DNA methylation assessment by high resolution melting (HRM) analysis}

Methylation levels of three DNA fragments located within the CpG rich region (Additional file 1) were determined by Real Time PCR amplification of bisulfite treated DNA, followed by HRM profile analysis by CFX96 ${ }^{\mathrm{TM}}$ Real-Time PCR Detection System, Bio-Rad Laboratories Inc. (Hercules, CA). For PCR amplification, $1 \mu \mathrm{l}$ solution of bisulfite treated DNA, from patients or standards, and primers (Additional file 1, Additional file 2) was added to $19 \mu \mathrm{l}$ of $5 \times$ Hot FIREPol EvaGreen HRM Mix, Solis BioDyne Co. (Tartu, Estonia). Standards of DNA methylation percentage were prepared by mixing in different ratio methylated and non-methylated bisulfite treated DNA from Human Methylated/Nonmethylated DNA Set Zymo Research Corp. (Orange, CA). To determine the percentage of methylation, the HRM profiles of patient DNA PCR products were compared with HRM profiles of standard DNA PCR product [24] (Additional file 3). HRM methylation analysis was performed using Precision Melt Analysis ${ }^{\mathrm{TM}}$ Software, Bio-Rad Laboratories Inc. (Hercules, CA). Each PCR amplification and HRM profile analysis was performed in triplicate. The methylation for each patient was presented as a percentage of methylation in three amplified fragments located in the CpG rich region of HSD17B1.

\section{ChIP analysis}

HT29 and SW707 cells were maintained in phenol redfree DMEM GibcoBRL supplemented with $10 \%$ charcoal-dextran-stripped FBS for 6, 12, 24, 36 and $48 \mathrm{~h}$ either in the absence or in the presence of 5-dAzaC at a concentration of $1.00 \mu \mathrm{M}$. Cells were then fixed by the addition of $270 \mu \mathrm{L}$ of $37 \%$ formaldehyde to $10 \mathrm{~mL}$ of culture medium for $10 \mathrm{~min}$ at $37{ }^{\circ} \mathrm{C}$, and harvested. Chromatin from $10^{6}$ cells was sheared by sonicator and precleared with salmon sperm DNA-saturated protein G sepharose. The ChIP assay was conducted using Abcam ChIP Kit ab500 [25]. Chromatin was incubated with 2 $\mu \mathrm{g}$ of rabbit polyclonal anti-Pol II Ab (H-224) overnight at $4{ }^{\circ} \mathrm{C}$. The input and immunoprecipitated DNA were used as templates for Real Time PCR preformed using the primers corresponding to the promoter of the HSD17B1 gene (Additional file 1, Additional file 2). The percentage of $H S D 17 B 1$ promoter that was bound with Pol II was calculated based on the differences between $\mathrm{C}_{\mathrm{T}}$ values for input and DNA samples from cells treated or untreated with 5-dAzaC.

\section{Effect of 5-dAzaC on the conversion of E1 to E2 in HT29 and SW707 cells}

To determine the effect of 5-dAzaC on the conversion of E1 to E2, the HT29 and SW707 cells were maintained for $24 \mathrm{~h}$ in phenol red-free DMEM GibcoBRL supplemented with $10 \%$ charcoal-dextran-stripped FBS from Sigma-Aldrich Co. Cells were then cultured for 36 $\mathrm{h}$ either in the absence or in the presence of 5-dAzaC at a concentration of $1.00 \mu \mathrm{M}$ for HT29 and SW707 cells. These cells were then further cultured either in the absence or the presence of $\mathrm{E} 1$ at a concentration of $10^{-2}$ $\mathrm{mM}$. After 2, 4, 6, 8, 10 and $12 \mathrm{~h}, 0.5 \mathrm{ml}$ of the medium was collected and the concentration of E2 was determined by electrochemiluminescence method using Cobas 6000 Roche Diagnostics GmbH (Mannheim, Germany). The results were expressed as E2 concentration in culture medium in $\mathrm{nM}$ per $\mu \mathrm{g}$ cell protein.

\section{Statistical analysis}

Data groups for cell lines were assessed by ANOVA to evaluate if there was significance $(P<0.05)$ between the groups. For all experimental groups, which fulfilled the initial criterion, individual comparisons were performed by post hoc Tukey test with the assumption of two-tailed distribution and two samples with equal variance at the $P<0.05$ level. Statistical significance was designated by asterisks in the figures.

The normality of the observed patient data distribution was assessed by Shapiro-Wilk test, and parametric unpaired, two-tailed $t$-test or nonparametric U-MannWhitney test was used to compare the mean values. $P<$ 0.05 was considered statistically significant. The correlation between mRNA and protein levels was evaluated by Spearman nonparametric correlation coefficient method. The statistical analysis was performed with STATISTICA 6.0 software. 


\section{Results}

HSD17B1 transcript and protein levels in primary cancerous and histopathologically unchanged tissues from patients with CRC

To compare HSD17B1 transcript and protein levels in cancerous and histopathologically unchanged tissues from patients with CRC we used RQ-PCR and western blotting analysis, respectively. We found significantly lower levels of HSD17B1 transcript ( $p=0.0016)$ and protein $(p=0.0028)$ in primary cancerous tissues than in histopathologically unchanged tissues in patients with $\mathrm{CRC}$ in the proximal colon (Figure $1 \mathrm{~A}, \mathrm{~B}, \mathrm{C}$ and Table 1). Moreover, we observed a moderate correlation between mRNA and protein in cancerous $(p=0.0502)$ and histopathologically unchanged tissue $(p=0.0722)$ in the proximal colon. We also observed significantly lower amounts of HSD17B1 transcript $(p=0.0335, p=$ $0.0388)$ and protein $(p=0.0659, p=0.2832)$ in cancerous tissues compared to histopathologically unchanged tissues in patients with G2 histological grade and male patient group, respectively. There were no significant differences in transcript $(p=0.1685, p=0.8839)$ and HSD17B1 protein ( $p=0.7763, p=0.5019)$ levels between primary cancerous and histopathologically unchanged tissues in patients with CRC located in the distal colon and rectum (Table 1 ). We also did not observe differences in HSD17B1 transcript and protein levels between these tissues in the female patient group, different ages, G1/G3 histological grade (Table 1), and different tumour stage (not shown).

\section{DNA methylation levels in primary cancerous and} histopathologically unchanged tissues from patients with CRC

To compare DNA methylation levels in the HSD17B1 CpG rich region between DNA from cancerous and histopathologically unchanged tissues, we performed sodium bisulfite DNA sequencing and HRM analysis (Additional file 1, Additional file 2). Bisulfite sequencing was used for preliminary evaluation of DNA methylation changes in randomly selected patients. We observed the same pattern of methylation within all individual clones of each patient. Moreover, this evaluation showed significant differences in DNA methylation levels between cancerous and histopathologically unchanged tissues from five patients with CRC in the proximal colon (Figure 2A). However, we did not observe this difference in five patients with CRC located in the distal colon (Figure $2 \mathrm{~B}$ ) or rectum (not shown). We applied HRM analysis of PCR amplified bisulfite treated DNA to extend the DNA methylation studies in the HSD17B1 CpG rich region for cancerous and histopathologically unchanged tissues from all fifty two patients. In patients with CRC

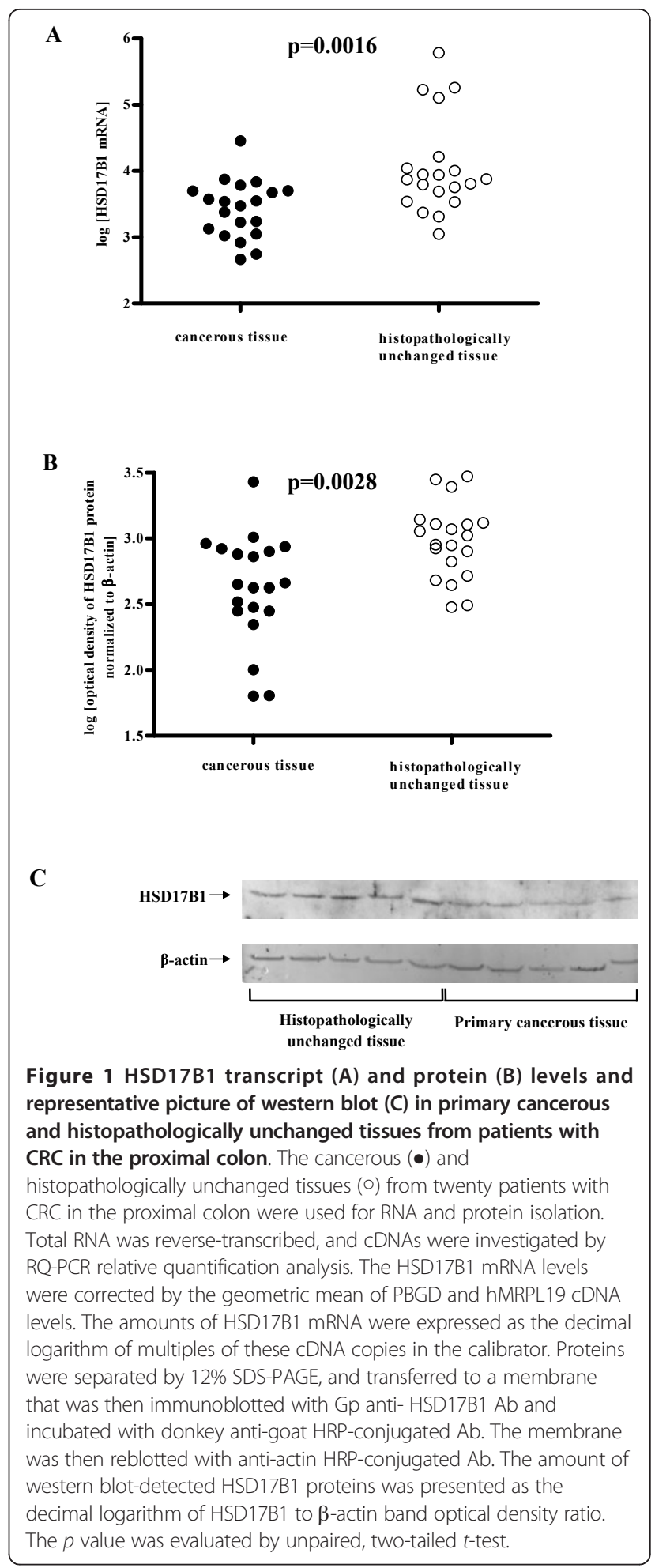

located in the proximal colon, we found a significantly higher DNA methylation percentage in cancerous than in histopathologically unchanged tissues $(p=0.003)$ (Table 2). However, there were no significant differences 


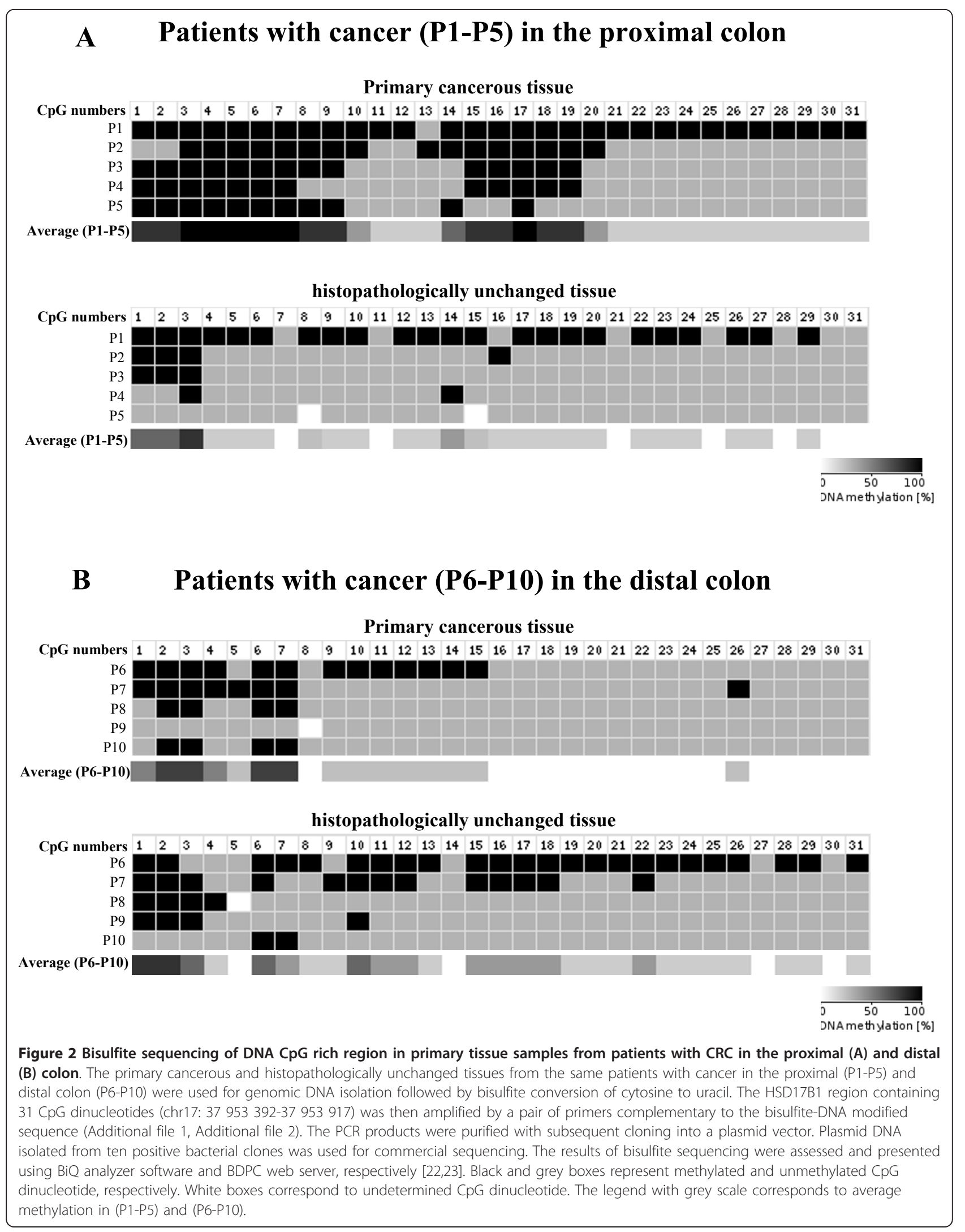


Table 2 The percentage of DNA methylation in CpG rich regions in primary cancerous and histopathologically unchanged tissue samples from patients with CRC.

\begin{tabular}{|c|c|c|c|c|c|c|}
\hline \multicolumn{2}{|l|}{$\mathrm{n}=52$} & \multicolumn{2}{|c|}{ Primary cancerous tissues } & \multicolumn{2}{|c|}{ Histopathologically unchanged tissues } & \multirow[t]{2}{*}{$p^{a}$} \\
\hline & & Median (range) & Mean $( \pm$ SD) & Median (range) & Mean ( \pm SD) & \\
\hline \multicolumn{7}{|l|}{ Age } \\
\hline$<60$ & 10 & $21.05(12.89-25.79)$ & $20.66 \pm 4.205$ & $19.47(13.16-28.42)$ & $19.32 \pm 4.875$ & 0.5181 \\
\hline$>60$ & 42 & $20.00(4.211-33.16)$ & $20.91 \pm 7.074$ & $18.95(2.105-36.21)$ & $18.42 \pm 6.779$ & 0.1076 \\
\hline \multicolumn{7}{|l|}{ Gender } \\
\hline Female & 20 & $24.21(16.84-33.16)$ & $24.42 \pm 4.516$ & $23.68(13.68-28.42)$ & $21.75 \pm 4.499$ & 0.1155 \\
\hline Male & 32 & $18.95(4.211-32.11)$ & $19.51 \pm 7.255$ & $17.37(2.105-36.21)$ & $18.43 \pm 7.206$ & 0.5594 \\
\hline \multicolumn{7}{|l|}{ CRC localization } \\
\hline Proximal colon (cecum to transverse) & 20 & $24.21(13.68-33.16)$ & $23.54 \pm 5.793$ & 17.63 ( 2.105435 .79$)$ & $17.61 \pm 6.050$ & 0.0030 \\
\hline Distal colon (splenic flexture to sigmoid) & 12 & $19.47(4.211-28.95)$ & $19.69 \pm 7.159$ & $18.95(10.53-25.26)$ & $18.85 \pm 4.747$ & 0.7498 \\
\hline Rectum & 20 & $19.47(6.316-28.42)$ & $19.36 \pm 6.292$ & $19.47(4.737-36.21)$ & $19.30 \pm 7.851$ & 0.9810 \\
\hline \multicolumn{7}{|l|}{ Histologic grade } \\
\hline G1 & 4 & $21.32(13.68-28.42)$ & $21.18 \pm 8.067$ & 17.89 (2.105-27.89) & $16.45 \pm 10.97$ & 0.5126 \\
\hline G2 & 35 & 20.00 (10.53-30.53) & $21.17 \pm 5.293$ & $19.47(4.737-28.42)$ & $18.93 \pm 5.884$ & 0.0996 \\
\hline G3 & 13 & $21.84(4.211-33.16)$ & $20.21 \pm 9.397$ & $15.53(12.63-36.21)$ & $18.11 \pm 6.727$ & 0.4021 \\
\hline
\end{tabular}

The primary cancerous and histopathologically unchanged tissue samples from the same patients were used for genomic DNA isolation, followed by bisulfite conversion of cytosine to uracil. The three DNA fragments of the CpG rich region were then amplified by three pairs of primers complementary to the bisulfiteDNA modified sequence (Additional file 1, Additional file 2). To determine the percentage of methylation, the HRM profiles of the patients' DNA PCR products were compared to HRM profiles of the prepared standard PCR products. DNA methylation for each patient was presented as a percentage of methylation in three DNA amplified fragments located in the CpG rich region (Additional file 1). ${ }^{a}$ Unpaired, two-tailed $t$-test.

in DNA methylation percentage between cancerous and histopathologically unchanged tissues from patients with CRC located in the distal colon $(p=0.7498)$ and rectum $(p=0.9810)$ (Table 2). We also did not find significant differences in the DNA methylation percentage between these tissues in patients divided based on gender, age, histological grade (Table 2) and tumour stage (not shown).

\section{5-dAzaC effects on HSD17B1 transcript and protein} contents in HT29 and SW707 colorectal cancer cells We observed that 5-dAzaC resulted in a progressive increase in HSD17B1transcript levels in HT29 and SW707 cells (Figure 3A,B). For HT29 cells, we found approximately a 1.91 - fold significant increase in HSD17B1 transcript levels at $48 \mathrm{~h}$ of incubation (Figure $3 \mathrm{~A})$. There was also an approximately 1.35 -fold significant increase in HSD17B1 mRNA in SW707 cells at $48 \mathrm{~h}$ of incubation (Figure 3B). These alterations in HSD17B1 transcript levels in both HT29 and SW707 cells were associated with increased HSD17B1 protein levels (Figure 4). Densitometric analysis of western blotting bands indicated a gradual increase of HSD17B1 protein levels in a dose dependent manner at 24, 36, and $48 \mathrm{~h}$ of incubation for HT29 cells, and at $48 \mathrm{~h}$ for SW707 cells (Figure 4). Incubation of HT29 cells with $5-\mathrm{dAzaC}$ at a concentration of $1.00 \mu \mathrm{M}$ for $48 \mathrm{~h}$ resulted in a 2.28 -fold increase in HSD17B1 protein contents (Figure 4). There was also an approximately 1.57 -fold increase in HSD17B1 protein contents in SW707 cells incubated with 5-dAzaC at a concentration of $1.00 \mu \mathrm{M}$ for $48 \mathrm{~h}$ as compared with the respective control (Figure 4).

\section{5-dAzaC induced transcription of HSD17B1 via DNA} demethylation in the $\mathrm{CpG}$ rich region and increased the binding of Pol II to the promoter in HT29 colon cancer cells In order to assess the effect of 5-dAzaC on DNA demethylation and Pol II binding to the promoter we used bisulfite DNA sequencing and the ChIP assay, respectively (Additional file 1 ). We noticed the same pattern of methylation within all analysed clones. Moreover, we observed significant DNA demethylation in the CpG rich region in HT29 cells cultured for $48 \mathrm{~h}$ in the presence of 5-dAzaC (Figure 5A). Incubation with 5$\mathrm{dAzaC}$ at a concentration of $1.00 \mu \mathrm{M}$ for $6,12,24,36$, and $48 \mathrm{~h}$ caused an approximately 1.56 to 6.70 -fold increase in the percentage of promoter occupancy by Pol II in HT29 colon cancer cells (Figure 5B). However, in SW707 CRC cells treated with 5-dAzaC at a concentration of $1.00 \mu \mathrm{M}$, we observed slight DNA demethylation and slight increased occupancy percentage of the promoter by Pol II (Figure 5A,B).

\section{5-dAzaC increased the conversion of E1 to E2 in HT29 and SW707 colorectal cancer cells}

5 -dAzaC caused a progressive increase in the conversion of $\mathrm{E} 1$ to $\mathrm{E} 2$ in a time dependent manner in 5-dAzaC pretreated HT29 cells at $6,8,10$ and $12 \mathrm{~h}$ of incubation (Figure 6A). Incubation of 5-dAzaC pretreated HT29 cells with $\mathrm{E} 1$ for $12 \mathrm{~h}$ resulted in a 3.0-fold increase in 


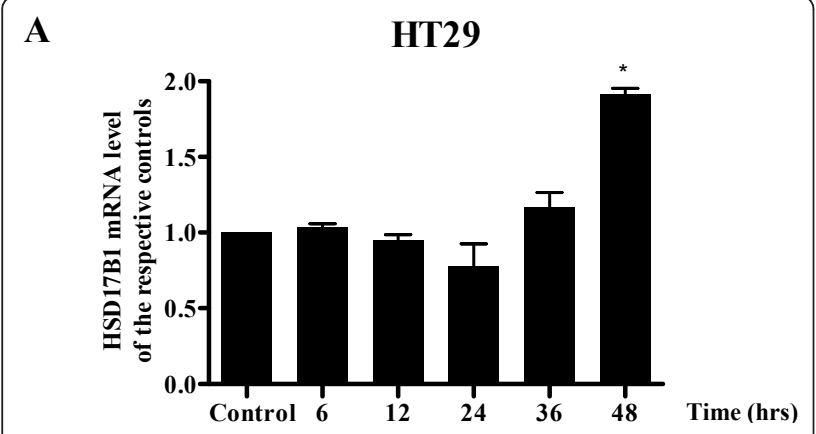

B

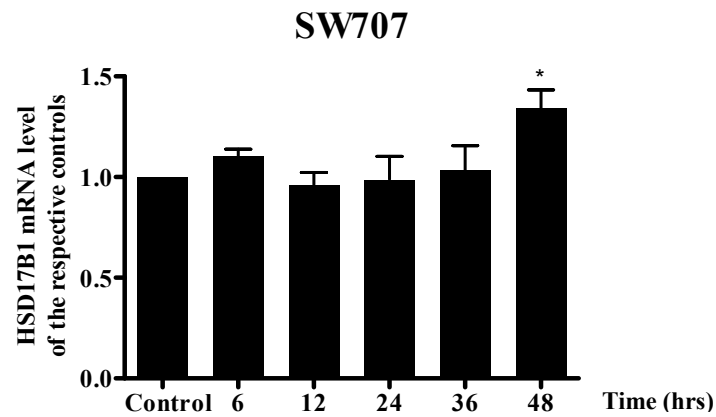

Figure 3 5-dAzaC up-regulates HSD17B1 transcript levels in HT29 (A) and SW707 (B) colorectal cancer cells. HT29 and SW707 cells were cultured in phenol red-free DMEM for 6, 12, 24, 36 and 48 h either in the absence or in the presence of 5-dAzaC at a concentration of 1.00 $\mu \mathrm{M}$. After incubation the cells were used for total RNA isolation and reverse transcription. The HSD17B1 CDNA levels were determined by $R Q-P C R$ relative quantification analysis. $R Q-P C R$ results were standardized by the geometric mean of PBGD and hMRPL19 CDNA levels. HSD17B1 cDNA levels are expressed as a multiplicity of the respective controls. Each sample was determined in triplicate and results are presented as the mean \pm SE from three experiments ${ }^{*} P<0.05$.

E2 levels as compared to 5-dAzaC untreated cells (Figure 6A). There was also a slight, 1.2-fold, increase in E2 concentration in 5 -dAzaC pretreated SW707 cells at 12 $\mathrm{h}$ of incubation as compared with the respective control (Figure 6B).

\section{Discussion}

There are many environmental, dietary, lifestyle, behavioral, genetic and epigenetic factors that have been considered as risk factors for developing CRC [26-30]. Malignant transformation of colonic mucosa to adenoma and adenocarcinoma is associated with the accumulation of mutations in various oncogenes, tumour suppressor genes (TSGs) and chromosome, and microsatellite instability [29,31]. Alternatively, the epigenetic mechanism has also been considered as a strong contributor to CRC incidence. Aberrant methylation of DNA may mimic DNA mutation, leading to transcriptional silencing of TSGs and chromosome instability [15].
Accessibility of E2 is another significant factor contributing to the development of CRC. The randomized clinical trial conducted by the Women's Health Institute showed that treatment of postmenopausal women with E2 plus progestin was associated with a decreased risk of CRC [32]. In contrast, treatment of these women with E2 alone exhibited a rather slight increased risk of CRC [32]. However, the importance of E2 in the prevention of large bowel tumorigenesis has been shown in other epidemiological studies [3,5,33]. E2 exerts an apoptotic effect in CRC cells mainly via interaction with the estrogen receptor (ER) [34-36]. This apoptotic effect of E2 in CRC can be inhibited by DNA methylation and silencing of transcription of the ESR2 gene encoding ER $\beta$ [35,37]. Papaxoinis et al. [38] showed that ESR2 expression is higher in normal epithelium of the proximal colon as compared to the distal colon. This indicated that epigenetic silencing of ESR2 appearing in 90\% of CRC cases could mainly be associated with carcinogenesis in the proximal colon [39]. Moreover, the cohort studies indicated that, in postmenopausal women, CRC more frequently developed in the proximal colon than in the distal colon $[40,41]$. These findings may indicate that the proximal colon may be the major bowel region, compared to the distal colon, in which E2 may mainly exert its anticancer action [42]. Fiorelli et al. (2002) showed the involvement of HSD17B1 in the conversion of E1 to E2 in human colon cancer cells [43]. This may suggest that the extragonadal production of E2 from E1, especially in the large bowel, may be critical in CRC incidence in postmenopausal women and in men.

During CRC development, epithelial cells acquire peculiar features which enable them to grow aberrantly, ignore growth inhibition, and resist death signals [44]. We found a significant reduction of HSD17B1 transcript and protein levels in CRC in the proximal colon. However, these differences were not found in CRC in the distal colon and rectum. The decreased expression of $H S D 17 B 1$ was associated with significantly increased DNA methylation in the $\mathrm{CpG}$ rich region located in the 5' flanking region of the $H S D 17 B 1$ gene in CRC in the proximal colon but not in the distal colon and rectum.

Abnormalities in DNA methylation are observed from the early stages of lesions in aberrant crypt foci and hyperplastic polyps considered to be CRC incidence risk factors $[45,46]$. To date, transcriptional silencing by DNA methylation has been demonstrated in $h M L H 1$, PDZ and LIM domain 2, UDP-glucuronosyltransferase 1A1, HOXB13, CXCL12 and other genes in CRC [31,47-50]. Moreover, there is a distinction between tumorigenesis associated with DNA methylation and gene expression when comparing the proximal colon to the distal colon and rectum [30,51]. Carcinogenesis in the proximal colon is mainly associated with epigenetic 


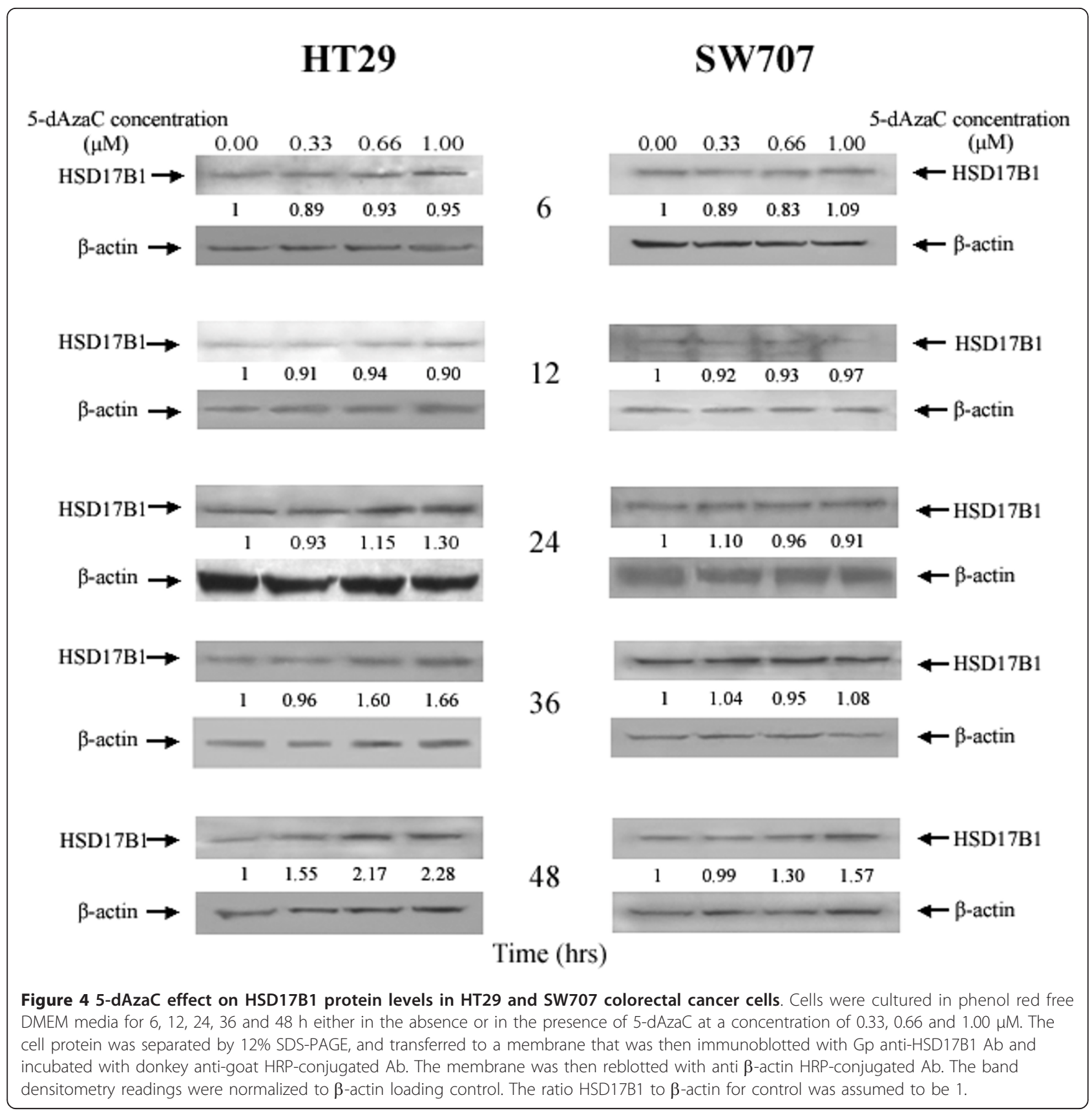

aberrations, whereas cancer incidence in the distal colon and rectum is mainly linked to the accumulation of genetic mutations [51]. Glebov et al. (2003) used microarray analysis to demonstrate that more than 1000 genes are expressed differently in CRC depending on its location in either the ascending or descending colon [52]. Toyota et al. (1999) characterized the CpG island methylator phenotype (CIMP) in CRC [53]. CRC with CIMP-high develops more frequently in the proximal colon, while CIMP-low or CIMP-negative is likely to be found in the distal colon [30,51]. Hypermethylation of the promoter region of $h M L H 1$, encoding a component of the DNA mismatch repair system, was also more frequently found in CRC in the proximal colon than in the distal colon [31].

In order to determine the role of methylation of the CpG rich region in HSD17B1 expression, we treated HT29 and SW707 cells with 5-dAzaC. We observed DNA demethylation within the CpG rich region (chr17: 37953 426-37 954 646) (Additional file 1), which was associated with an increase in Pol II binding to the promoter and increased the HSD17B1 transcript 


\section{HT29}

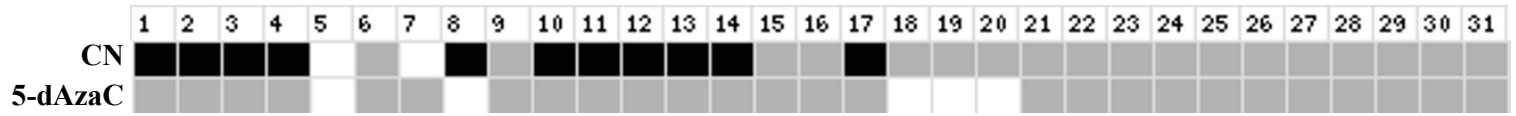

A

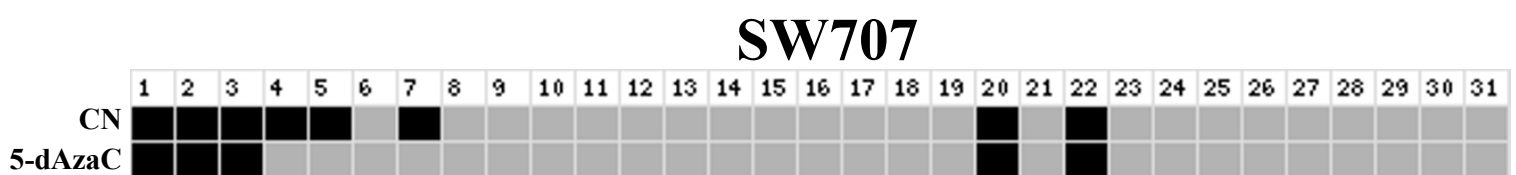

B

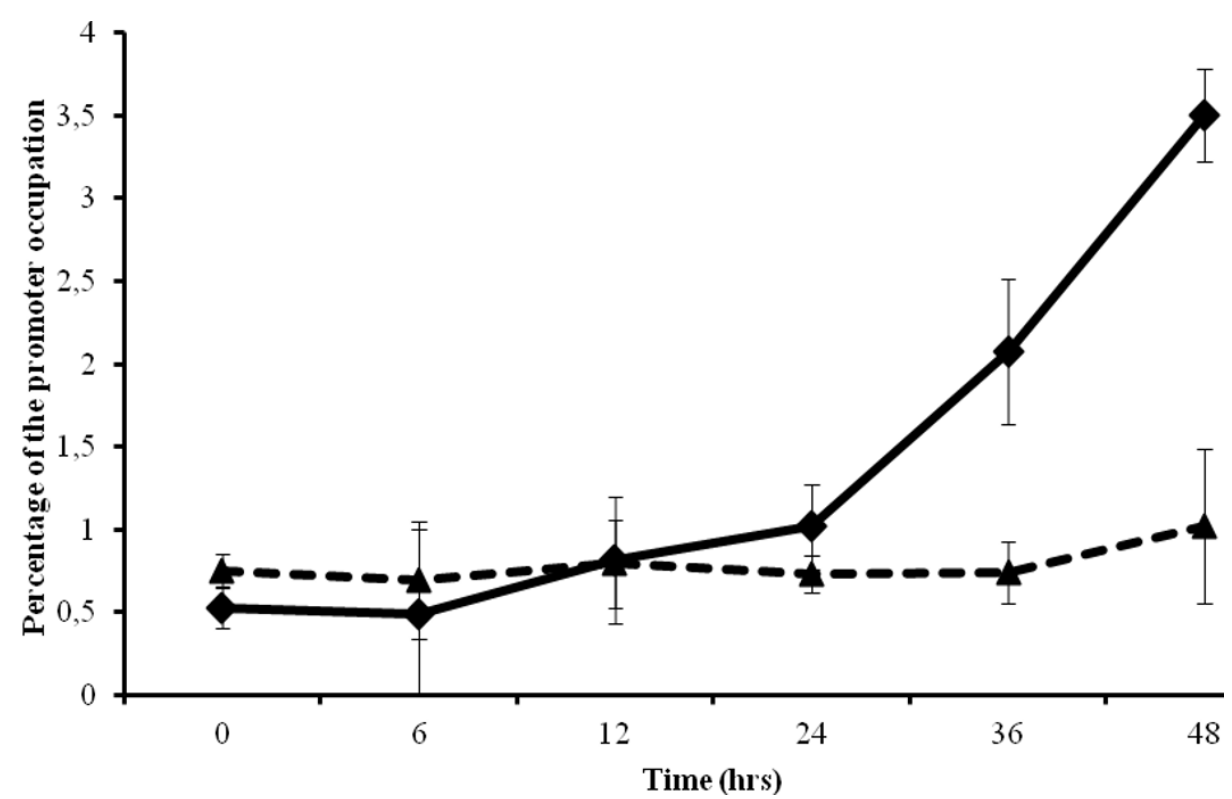

Figure 5 Bisulfite sequencing of the CpG rich region fragment (A) and binding of Pol II to HSD17B1 promoter (B) in HT29 and SW707 colorectal cancer cells treated with 5-dAzaC. HT29 and SW707 cells were incubated for $48 \mathrm{~h}$ either in the absence or in the presence of 5$\mathrm{dAzaC}(1.00 \mu \mathrm{M})$. The cells were then used for genomic DNA isolation followed by bisulfite conversion of cytosine to uracil. The CpG rich region containing 31 CpG dinucleotides (chr17: 37953 392-37 953 917) was then amplified by a pair of primers complementary to the bisulfite-DNA modified sequence (Additional file 1, Additional file 2). The PCR products were purified with subsequent cloning into a plasmid vector. Plasmid DNA isolated from ten positive bacterial clones was used for commercial sequencing. The results of bisulfite sequencing were assessed and presented using BiQ analyzer software and BDPC web server, respectively [22,23]. Black and grey boxes represent methylated and unmethylated CpG dinucleotide, respectively. White boxes correspond to undetermined CpG dinucleotide. For the ChIP assay, HT29 and SW707 cells were incubated for $0,6,12,24,36$, and $48 \mathrm{~h}$ either in the absence or in the presence of 5-dAzaC (1.00 $\mu \mathrm{M})$. After incubation, cells were used for ChIP analysis with anti-Pol II Ab. RQ-PCR was carried out by pairs of primers complementary to the HSD17B1 promoter for the HT29 (- -) and SW707 (.......) cell lines (Additional file 1, Additional file 2). Data are expressed as a percentage of the HSD17B1 promoter occupied by Pol II. The results are presented as the mean \pm SE from three independent experiments.

and protein levels in HT29 cells. However, 5-dAzaC treatment caused lower DNA demethylation and binding of Pol II to promoter in SW707 cells than in HT29 cells. These differences between HT29 and SW707 cells might be due to their distinct regions of origin from the large bowel: SW707 cells were derived from the rectum, whereas HT29 originated from the colon $[54,55]$.

Data from the Encyclopedia of DNA elements project showed that the analyzed $\mathrm{CpG}$ rich region upstream of HSD17B1 (chr17: 37953 426-37 954 646) is able to bind various transcription factors. Moreover, the 


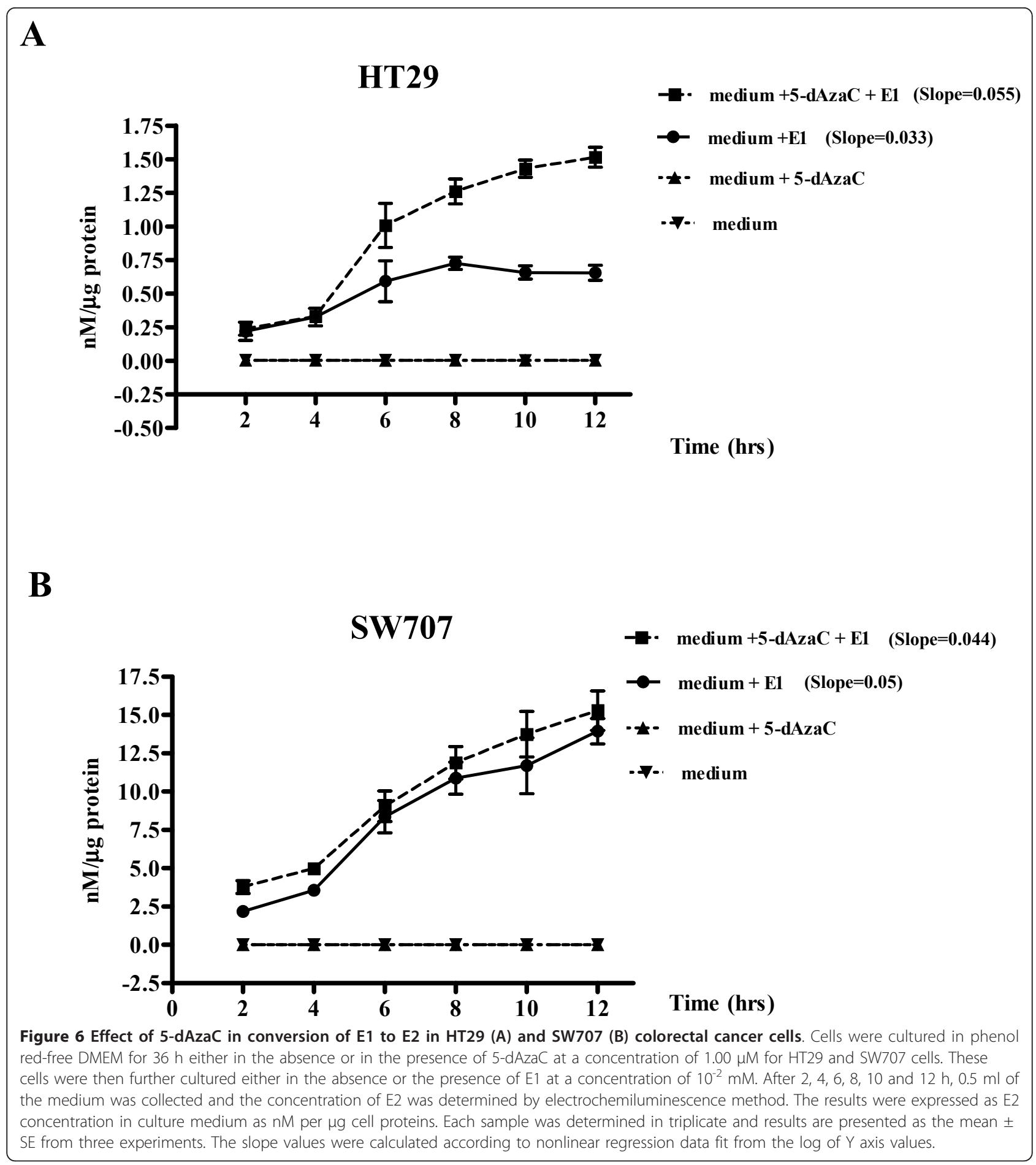

enrichment of histone modification and DNAse I hypersensitivity of that region suggest promoter or enhancer activity [56]. Lornicz et al. (2004) showed that DNA methylation in intragenic and intergenic CpG rich regions may convert euchromatin to heterochromatin and lead to reduced Pol II action [57]. Based on this observation, we hypothesize that hypermethylation of the 5 ' flanking region of the $H S D 17 B 1$ gene might inhibit the binding of transcription factors and decrease HSD17B1 expression in CRC.

5-dAzaC has been considered in the treatment of CRC. Genome-wide studies, including promoter methylation and expression microarray analysis, revealed a number of genes that are up-regulated in SW116 and 
Colo-320 CRC cells treated with 5-dAzaC [58]. This DNMTs inhibitor also results in DNA demethylation and induces the expression of PDZ and LIM domain 2, UDP-glucuronosyltransferase 1A1, insulin-like growth factor binding protein 7 , and NGX6 genes in CRC cells $[47,48,59,60]$. Lin et al. (2008) demonstrated that 5$\mathrm{dAzaC}$ induced apoptosis and inhibited the growth, migration and invasion of colon cancer cells [60].

\section{Conclusion}

Our results showed increased DNA methylation in the 5' flanking region of $H S D 17 B 1$ in CRC from the proximal colon as compared to normal colonic epithelium. These epigenetic differences were associated with a significant reduction of $H S D 17 B 1$ transcript and protein levels in cancer located in the proximal colon. We also found that 5-dAzaC, an inhibitor of DNMTs, induced the demethylation of the 5 ' flanking region of HSD17B1, leading to increased transcript and protein levels in HT29 colon cancer cells, which contributed to the increase in E2 formation.

Although we presented that $H S D 17 B 1$ expression in CRC can be epigenetically down-regulated, further studies are required to assess the concentration of endogenous E2 in normal colonic tissue and the role of endogenous E2 in the prevention of carcinogenesis.

\section{Additional material}

Additional file 1: Organization of the HSD17B1 gene (A), the

positions of $\mathrm{CpG}$-rich regions and promoter

Additional file 2: Primer sequences.

Additional file 3: DNA methylation assessment by HRM analysis.

\begin{abstract}
Acknowledgements
Supported by grant No 502-01-01124182-07474, Poznań University of Medical Sciences. The authors wish to acknowledge Dr. Margarita Lianeri for her assistance.

\section{Author details}

'Department of Biochemistry and Molecular Biology, Poznań University of Medical Sciences, Poznań Poland. ${ }^{2}$ Department of General and Colorectal Surgery, Poznań University of Medical Sciences, Poznań Poland.
\end{abstract}

\section{Authors' contributions}

AAR contributed to designing the study, acquisition of data, analysis and interpretation of data, and in writing the manuscript. $\mathrm{KH}$ participated in the acquisition and interpretation of the data. As Principal Investigators, PK and JPP were involved in the intellectual and experimental programming of the study, the interpretation of data, and writing the manuscript. All authors read and approved the final manuscript.

\section{Competing interests}

The authors declare that they have no competing interests.

Received: 13 July 2011 Accepted: 19 December 2011

Published: 19 December 2011
References

1. Jemal A, Siegel R, Xu J, Ward E: Cancer statistics, 2010. CA Cancer J Clin 2010, 60(5):277-300.

2. Ferlay J, Parkin DM, Steliarova-Foucher E: Estimates of cancer incidence and mortality in Europe in 2008. Eur J Cancer 2008, 46(4):765-781.

3. Brenner $H$, Hoffmeister $M$, Arndt $V$, Haug U: Gender differences in colorectal cancer: implications for age at initiation of screening. $\mathrm{Br} J$ Cancer 2007, 96(5):828-831.

4. Ries LA, Wingo PA, Miller DS, Howe HL, Weir HK, Rosenberg HM, Vernon SW, Cronin K, Edwards BK: The annual report to the nation on the status of cancer, 1973-1997, with a special section on colorectal cancer. Cancer 2000, 88(10):2398-2424.

5. Qiu Y, Langman MJ, Eggo MC: Targets of 17beta-oestradiol-induced apoptosis in colon cancer cells: a mechanism for the protective effects of hormone replacement therapy? J Endocrinol 2004, 181(2):327-337.

6. Nelson HD, Humphrey LL, Nygren P, Teutsch SM, Allan JD: Postmenopausal hormone replacement therapy: scientific review. Jama 2002, 288(7):872-881.

7. Rennert G, Rennert HS, Pinchev M, Lavie O, Gruber SB: Use of hormone replacement therapy and the risk of colorectal cancer. J Clin Oncol 2009, 27(27):4542-4547.

8. Simpson ER: Sources of estrogen and their importance. J Steroid Biochem Mol Biol 2003, 86(3-5):225-230.

9. Mindnich R, Moller G, Adamski J: The role of 17 beta-hydroxysteroid dehydrogenases. Mol Cell Endocrinol 2004, 218(1-2):7-20.

10. Luu The V, Labrie C, Zhao HF, Couet J, Lachance Y, Simard J, Leblanc G, Cote J, Berube D, Gagne R, et al: Characterization of cDNAs for human estradiol 17 beta-dehydrogenase and assignment of the gene to chromosome 17: evidence of two mRNA species with distinct $5^{\prime}$-termini in human placenta. Mol Endocrinol 1989, 3(8):1301-1309.

11. Luu-The V, Labrie C, Simard J, Lachance Y, Zhao HF, Couet J, Leblanc G, Labrie F: Structure of two in tandem human 17 beta-hydroxysteroid dehydrogenase genes. Mol Endocrinol 1990, 4(2):268-275.

12. Miettinen MM, Mustonen MV, Poutanen MH, Isomaa W, Vihko RK: Human 17 beta-hydroxysteroid dehydrogenase type 1 and type 2 isoenzymes have opposite activities in cultured cells and characteristic cell- and tissue-specific expression. Biochem J 1996, 314(Pt 3):839-845.

13. Poutanen $M$, Moncharmont B, Vihko R: 17 beta-hydroxysteroid dehydrogenase gene expression in human breast cancer cells: regulation of expression by a progestin. Cancer Res 1992, 52(2):290-294.

14. Kondo Y: Epigenetic cross-talk between DNA methylation and histone modifications in human cancers. Yonsei Med J 2009, 50(4):455-463.

15. Luczak MW, Jagodzinski PP: The role of DNA methylation in cancer development. Folia Histochem Cytobiol 2006, 44(3):143-154.

16. Chomczynski $P$, Sacchi N: Single-step method of RNA isolation by acid guanidinium thiocyanate-phenol-chloroform extraction. Anal Biochem 1987, 162(1):156-159.

17. Radonic A, Thulke S, Mackay IM, Landt O, Siegert W, Nitsche A: Guideline to reference gene selection for quantitative real-time PCR. Biochem Biophys Res Commun 2004, 313(4):856-862.

18. Szabo A, Perou CM, Karaca M, Perreard L, Palais R, Quackenbush JF, Bernard PS: Statistical modeling for selecting housekeeper genes. Genome Biol 2004, 5(8):R59.

19. EMBOSS CpGPlot/CpGReport/Isochore. [http://www.ebi.ac.uk/emboss/ cpgplot/].

20. CpG Island Searcher. [http://cpgislands.usc.edu/].

21. UCSC Genome Bioinformatics Site. [http://genome.ucsc.edu/].

22. Bock C, Reither S, Mikeska T, Paulsen M, Walter J, Lengauer T: BiQ Analyzer: visualization and quality control for DNA methylation data from bisulfite sequencing. Bioinforma (Oxford, England) 2005, 21(21):4067-4068.

23. Rohde C, Zhang Y, Jurkowski TP, Stamerjohanns $H$, Reinhardt $R$, Jeltsch A: Bisulfite sequencing Data Presentation and Compilation (BDPC) web server-a useful tool for DNA methylation analysis. Nucleic Acids Res 2008, 36(5):e34.

24. Wojdacz TK, Dobrovic A: Methylation-sensitive high resolution melting (MS-HRM): a new approach for sensitive and high-throughput assessment of methylation. Nucleic Acids Res 2007, 35(6):e41.

25. Abcam ChIP kit protocol. [http://www.abcam.com/index.html? pageconfig $=$ protocols\&pid $=1124 \&$ int $A b \mid D=500 \&$ strTab $=$ protocols $\&$ mode=prot]. 
26. Kim YI: Nutritional epigenetics: impact of folate deficiency on DNA methylation and colon cancer susceptibility. J Nutr 2005, 135(11):2703-2709.

27. Hermann S, Rohrmann S, Linseisen J: Lifestyle factors, obesity and the risk of colorectal adenomas in EPIC-Heidelberg. Cancer Causes Control 2009, 20(8):1397-1408

28. van Duijnhoven FJ, Bueno-De-Mesquita HB, Ferrari $P$, Jenab M, Boshuizen HC, Ros MM, Casagrande C, Tjonneland A, Olsen A, Overvad K, et al: Fruit, vegetables, and colorectal cancer risk: the European Prospective Investigation into Cancer and Nutrition. American $J$ Clin Nutr 2009, 89(5):1441-1452.

29. Fearon ER, Vogelstein B: A genetic model for colorectal tumorigenesis. Cell 1990, 61(5):759-767.

30. Kim MS, Lee J, Sidransky D: DNA methylation markers in colorectal cancer. Cancer Metastasis Rev 2010, 29(1):181-206.

31. Miyakura Y, Sugano K, Konishi F, Ichikawa A, Maekawa M, Shitoh K, Igarashi S, Kotake K, Koyama Y, Nagai H: Extensive methylation of hMLH1 promoter region predominates in proximal colon cancer with microsatellite instability. Gastroenterol 2001, 121(6):1300-1309.

32. Chlebowski RT, Wactawski-Wende J, Ritenbaugh C, Hubbell FA, Ascensao J, Rodabough RJ, Rosenberg CA, Taylor VM, Harris R, Chen C, et al: Estrogen plus progestin and colorectal cancer in postmenopausal women. New England J Med 2004, 350(10):991-1004.

33. Rossouw JE, Anderson GL, Prentice RL, LaCroix AZ, Kooperberg C, Stefanick ML, Jackson RD, Beresford SA, Howard BV, Johnson KC, et al: Risks and benefits of estrogen plus progestin in healthy postmenopausal women: principal results From the Women's Health Initiative randomized controlled trial. JAMA 2002, 288(3):321-333.

34. Hartman J, Edvardsson K, Lindberg K, Zhao C, Williams C, Strom A, Gustafsson JA: Tumor repressive functions of estrogen receptor beta in SW480 colon cancer cells. Cancer Res 2009, 69(15):6100-6106.

35. Castiglione F, Taddei A, Degl'Innocenti DR, Buccoliero AM, Bechi P, Garbini F, Chiara FG, Moncini D, Cavallina G, Marascio L, et al: Expression of estrogen receptor beta in colon cancer progression. Diagn Mol Pathol 2008, 17(4):231-236.

36. Weige CC, Allred KF, Allred CD: Estradiol alters cell growth in nonmalignant colonocytes and reduces the formation of preneoplastic lesions in the colon. Cancer Res 2009, 69(23):9118-9124.

37. Zhao C, Dahlman-Wright K, Gustafsson JA: Estrogen receptor beta: an overview and update. Nucl Recept signal 2008, 6:e003.

38. Papaxoinis K, Triantafyllou K, Sasco AJ, Nicolopoulou-Stamati P, Ladas SD: Subsite-specific differences of estrogen receptor beta expression in the normal colonic epithelium: implications for carcinogenesis and colorectal cancer epidemiology. Eur I Gastroenterol Hepatol 2010, 22(5):614-619.

39. Issa JP, Ottaviano YL, Celano P, Hamilton SR, Davidson NE, Baylin SB: Methylation of the oestrogen receptor $\mathrm{CpG}$ island links ageing and neoplasia in human colon. Nat Genet 1994, 7(4):536-540.

40. McCashland TM, Brand R, Lyden E, de Garmo P: Gender differences in colorectal polyps and tumors. Am J Gastroenterol 2001, 96(3):882-886.

41. Sarli L, Michiara M, Sgargi P, lusco D, De Lisi V, Leonardi F, Bella MA Sgobba G, Roncoroni L: The changing distribution and survival of colorectal carcinoma: an epidemiological study in an area of northern Italy. Eur J Gastroenterol Hepatol 2005, 17(5):567-572.

42. Cho NL, Javid SH, Carothers AM, Redston M, Bertagnolli MM: Estrogen receptors alpha and beta are inhibitory modifiers of Apc-dependent tumorigenesis in the proximal colon of Min/+ mice. Cancer Res 2007, 67(5):2366-2372

43. Fiorelli G, Picariello L, Martineti V, Tognarini I, Tonelli F, Brandi ML: Estrogen metabolism in human colorectal cancer cells. I Steroid Biochem Mol Biol 2002, 81(3):281-289.

44. Hanahan D, Weinberg RA: The hallmarks of cancer. Cell 2000, 100(1):57-70.

45. Chan AO, Broaddus RR, Houlihan PS, Issa JP, Hamilton SR, Rashid A: CpG island methylation in aberrant crypt foci of the colorectum. Am J Pathol 2002, 160(5):1823-1830.

46. Suehiro Y, Hinoda Y: Genetic and epigenetic changes in aberrant crypt foci and serrated polyps. Cancer Sci 2008, 99(6):1071-1076.

47. Qu Z, Yan P, Fu J, Jiang J, Grusby MJ, Smithgall TE, Xiao G: DNA methylation-dependent repression of PDZ-LIM domain-containing protein 2 in colon cancer and its role as a potential therapeutic target. Cancer Res 2010, 70(5):1766-1772.
48. Belanger AS, Tojcic J, Harvey M, Guillemette C: Regulation of UGT1A1 and HNF1 transcription factor gene expression by DNA methylation in colon cancer cells. BMC mol biol 2010, 11:9.

49. Ghoshal K, Motiwala T, Claus R, Yan P, Kutay H, Datta J, Majumder S, Bai S, Majumder A, Huang T, et al: HOXB13, a target of DNMT3B, is methylated at an upstream CpG island, and functions as a tumor suppressor in primary colorectal tumors. PloS one 2010, 5(4):e10338.

50. Wendt MK, Johanesen PA, Kang-Decker N, Binion DG, Shah V, Dwinell MB: Silencing of epithelial CXCL12 expression by DNA hypermethylation promotes colonic carcinoma metastasis. Oncogene 2006, 25(36):4986-4997.

51. Jass JR: Classification of colorectal cancer based on correlation of clinical, morphological and molecular features. Histopathol 2007, 50(1):113-130.

52. Glebov OK, Rodriguez LM, Nakahara K, Jenkins J, Cliatt J, Humbyrd CJ, DeNobile J, Soballe P, Simon R, Wright G, et al: Distinguishing right from left colon by the pattern of gene expression. Cancer Epidemiol Biomarkers Prev 2003, 12(8):755-762.

53. Toyota M, Ahuja N, Ohe-Toyota M, Herman JG, Baylin SB, Issa JP: CpG island methylator phenotype in colorectal cancer. Proc Natl Acad Sci USA 1999, 96(15):8681-8686.

54. Leibovitz A, Stinson JC, McCombs WB, McCoy CE, Mazur KC, Mabry ND: Classification of human colorectal adenocarcinoma cell lines. Cancer Res 1976, 36(12):4562-4569.

55. von Kleist S, Chany E, Burtin P, King M, Fogh J: Immunohistology of the antigenic pattern of a continuous cell line from a human colon tumor. $J$ Natl Cancer Inst 1975, 55(3):555-560

56. Site UGB: UCSC Genome Bioinformatics Site.

57. Lorincz MC, Dickerson DR, Schmitt M, Groudine M: Intragenic DNA methylation alters chromatin structure and elongation efficiency in mammalian cells. Nat Struct Mol Biol 2004, 11(11):1068-1075.

58. Tian $X Q$, Zhang $Y$, Sun $D$, Zhao $S$, Xiong $H$, Fang J: Epigenetic silencing of LRRC3B in colorectal cancer. Scand J gastroenterol 2009, 44(1):79-84.

59. Liu M, Peng Y, Wang X, Guo Q, Shen S, Li G: NGX6 gene mediated by promoter methylation as a potential molecular marker in colorectal cancer. BMC Cancer 2010, 10:160.

60. Lin J, Lai M, Huang Q, Ruan W, Ma Y, Cui J: Reactivation of IGFBP7 by DNA demethylation inhibits human colon cancer cell growth in vitro. Cancer biol ther 2008, 7(12):1896-1900

\section{Pre-publication history}

The pre-publication history for this paper can be accessed here: http://www.biomedcentral.com/1471-2407/11/522/prepub

doi:10.1186/1471-2407-11-522

Cite this article as: Rawłuszko et al:: Decreased expression of $17 \beta-$ hydroxysteroid dehydrogenase type 1 is associated with DNA hypermethylation in colorectal cancer located in the proximal colon. BMC Cancer 2011 11:522

\section{Submit your next manuscript to BioMed Central and take full advantage of:}

- Convenient online submission

- Thorough peer review

- No space constraints or color figure charges

- Immediate publication on acceptance

- Inclusion in PubMed, CAS, Scopus and Google Scholar

- Research which is freely available for redistribution 